\title{
LIFE CYCLE ASSESSMENT IN MANAGEMENT OF SOCIALLY RESPONSIBLE ENTERPRISE
}

\author{
Stanisław TKACZYK \\ Warsaw University of Technology, Faculty of Management, Warsaw, Poland \\ e-mail: s.tkaczyk@wz.pw.edu.pl \\ Joanna KUZINCOW*, Grzegorz GANCZEWSKI** \\ COBRO - Packaging Research Institute, Warsaw, Poland \\ *e-mail: redakcja@cobro.org.pl \\ **e-mail: ganczewski@cobro.org.pl
}

\begin{abstract}
The following paper presents dangerous and evident phenomenon of communicational chaos in the field of environment protection and sustainable development in a turbulent external environment. It is pointed that this phenomenon gives organizations an opportunity to take pretended pro-environmental actions, such as socially critical greenwashing. As a counterbalance to those practices, a concept of Corporate Social Responsibility (CSR) is presented, underlining the possibility of developing honest environmental marketing basing on methods such as Life Cycle Assessment.
\end{abstract}

Keywords: Corporate Social Responsibility (CSR), carbon footprint, greenwashing, management, marketing, communicational chaos, turbulent environment, Life Cycle Assessment (LCA).

\section{$1 \quad$ Introduction}

Constantly changing conditions of external environment intensify possibilities of unpredictable occurrences and in effect a threatening image crisis of an organization. Nowadays this is even more severe due to new technologies - the flow of information happens at almost the speed of light and events spread as fast as never before, causing tremendous turbulences [1].

Rapid pace of production and emphasis on lowering costs are accompanied by risk and uncertainty and therefore require a necessity of operational security. Organizations lean towards concepts such as sustainable development, which constitute a natural antidote for negative voices of public opinion and enable to rebuild frayed image.

Turbulent external environment is linked to clearly noticeable chaos - including communication chaos, which creates an opportunity to undertake pretended CSR actions in a form of greenwashing, dangerous from both environmental and social perspective. Successful method of countering such practices is promotion of more objective methods of environmental impact assessment, such as Life Cycle Assessment (LCA).

First of all, it should be emphasized, that LCA is one of the most objective study methods of environmental influences of organizations-enterprises, but actually every type of people activity. Although it is never possible to eliminate so called human factor, connected with objects' choice, parameters choice, or individual interpretation, the endpoint of this kind of life cycle research are numerical results which enable relatively accurate assessment and comparison. Such numerical result would be especially desirable in sustainability and corporate responsibility studies, where we can observe clear lack of objective criteria and there are rather guidelines than rules mentioned. Sometimes a reference point for sustainable development become legal regulations: to obey the law, but very often it is not enough to be sustained.

According to all above questions, implementation of LCA, as a general method of system inputs and outputs investigation and as a useful research technique, can be very important for development of CSR and sustainability concepts, making a big contribution both to economic science and to practical management activities. In the future it should also be possible to avoid not only definitional or measurement problems but also such, described below, dangerous phenomena as greenwashing and other examples of green noise or informational chaos, especially connected with turbulent, demanding continuous competence confirmation, environment. It should also give the enterprises the best possible communication tool in accordance with the principle of transparency. 
As mentioned, LCA results can be used for responsible and effective environmental communications, especially desired in the era of so-called greenwashing. Concept of greenwashing was coined in 1986 by ecologist Jay Westervelt in an essay concerning actions of hotel industry. Hotels recommended guests to dispose of their towels less often, allegedly taking the view of environmental awareness, but in effect this practice was imposed to reduce costs [2]. Horiuchi, Schuchard, Shae, and Townsend, authors of report called Understanding and Preventing Greenwash: A Business Guide, give two definitions of greenwashing. First one comes from the Oxford English Dictionary - "Disinformation disseminated by an organization, etc., so as to present an environmentally responsible public image; a public image of environmental responsibility promulgated by or for an organization, etc., but perceived as being unfounded or intentionally misleading." The other definition was taken from Lincoln Star Journal and is more explicit - "little green lies" [3].

Authors of the report have also spotted so called " 10 Signs of Greenwash", which can be a confirmation of deliberate disinformation in the image creating [3]:

1) Fluffy language: words or terms with no clear meaning (e.g. eco-friendly).

2) Green product vs. dirty company: such as efficient lightbulbs made in a factory that pollutes rivers.

3) Suggestive pictures: green images that indicate a (unjustified) green impact (e.g. flowers blooming from exhaust pipes).

4) Irrelevant claims: Emphasizing one tiny green attribute when everything else is not green.

5) Best in class: declaring you are slightly greener than the rest, even if the rest are pretty terrible.

6) Just not credible: "eco-friendly" cigarettes, anyone? "Greening" a dangerous product does not make it safe.

7) Jargon: Information that only a scientist could check or understand.

8) Imaginary friends: a "label" that looks like third party endorsement-except that it's made up.

9) No proof: it could be right, but where's the evidence?

10) Outright lying: totally fabricated claims or data.

In other version of greenwashing analysis, there is presented another version of mentioned signs [4]. The list is shorter and includes only six signs (only what should be emphasized), but general concept remains the same. Those six evidences of greenwashing have been vividly called sins [4]:

1) Sin of the Hidden Trade-Off - such claims are not usually false, but are used to paint a greener picture of the product than a more complete environmental analysis would support. This sin is committed by suggesting a product is green based on a single environmental attribute like the recycled content of paper, or an unreasonably narrow set of attributes, such as recycled content and chlorine-free bleaching, without attention to other important, or perhaps more important, environmental issues like energy, global warming, water, and forestry impacts of paper [4].

2) Sin of No Proof - environmental claim not substantiated by easily accessible supporting information, or by a reliable third-party certification. Example of such sin is: household lamps and lights that promote their energy efficiency without any supporting evidence or certification or personal care products that claim not to have been tested on animals, but offer no evidence or certification of this claim [4].

3) Sin of Vagueness - committed by every claim that is so poorly defined or broad that its real meaning is likely to be misunderstood by the intended consumer. Such sin of No Proof is very often connected with specific vague labels, like: chemical free or all natural. As a visual example vagueness sin there is mentioned the so called Moebius Loop (Fig. 1) that is designed to show, that the product is produced from recycled materials, but very often actual content of such raw material remains unclear, especially for the consumer.

4) Sin of Irrelevance - environmental claim that may be truthful but is unimportant and unhelpful for consumers seeking environmentally preferable products. It is irrelevant and therefore distracts the consumer from finding a truly greener option. The most frequent example of an irrelevant claim relates to chlorofluorocarbons (Fig. 2) - a principal contributor to ozone depletion. Since chlorofluorocarbons have been legally banned for almost 30 years, there are no products that are manufactured with it [4]. 


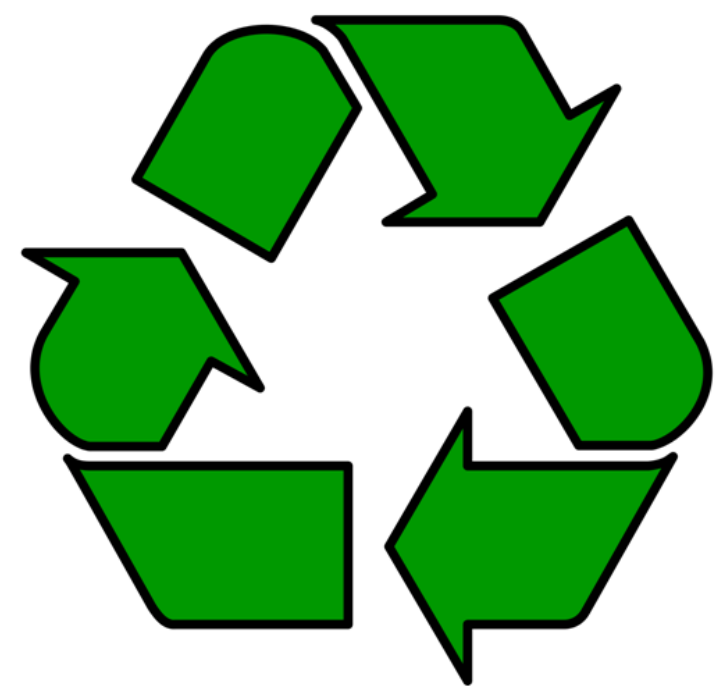

Figure 1. Moebius Loop-sign of recycling material content

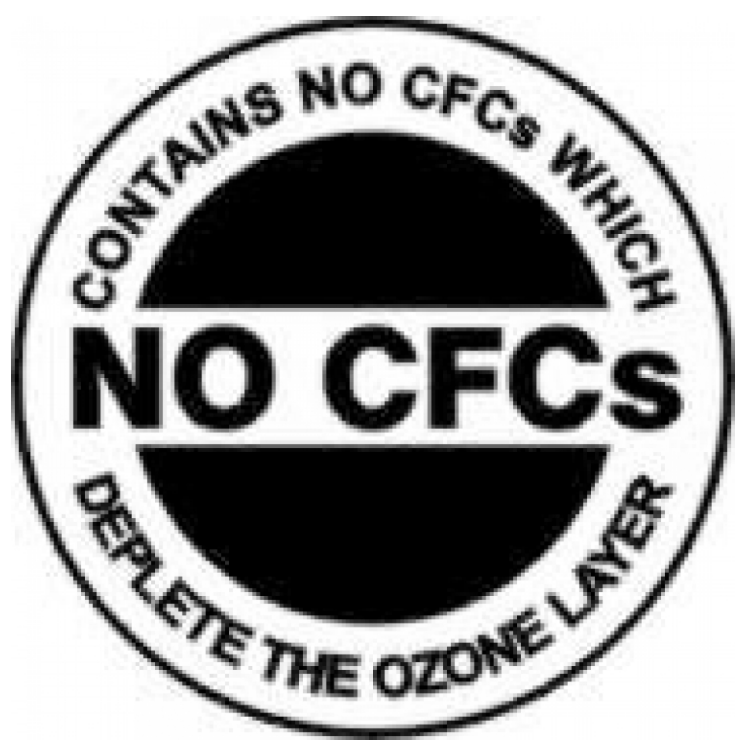

Figure 2. No chlorofluorocarbons sign (source: Company Press Service)

5) Sin of Fibbing - committed by making environmental claims that are simply false. In authors' findings, only a few products were found to commit the Sin of Fibbing. Most of these were misuse or misrepresentation of certification by an independent authority [4].

6) Sin of Lesser of Two Evils - claims that may be true within the product category, but that risk distracting the consumer from the greater environmental impacts of the category as a whole. Exam-
Examples include: organic cigarettes or green herbicides [4].

Percentage of documented cases of six sins of greenwashing presents chart on Fig. 3 [4].

As a result of greenwashing research, there were identified four types of environmental actions. Value to the environment and effectiveness of communications matrix is presented in Fig. 4 [3]. 


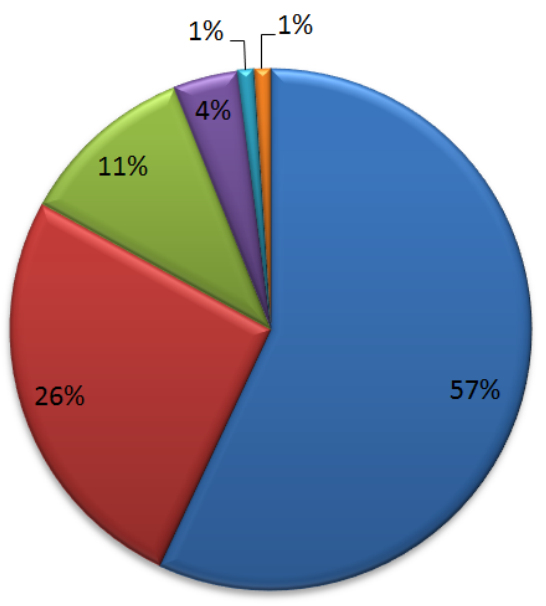
$\square$ THE SIN OF THE HIDDEN TRADE-OFF
$\square$ THE SIN OF IRRELEVANCE
口 THE SIN OF NO PROOF
$\square$ THE SIN OF FIBBING
$\square$ THE SIN OF VAGUENESS
$\square$ THE SIN OF LESSER OF TWO EVILS

Figure 3. Six sins of greenwashing (source: [4])

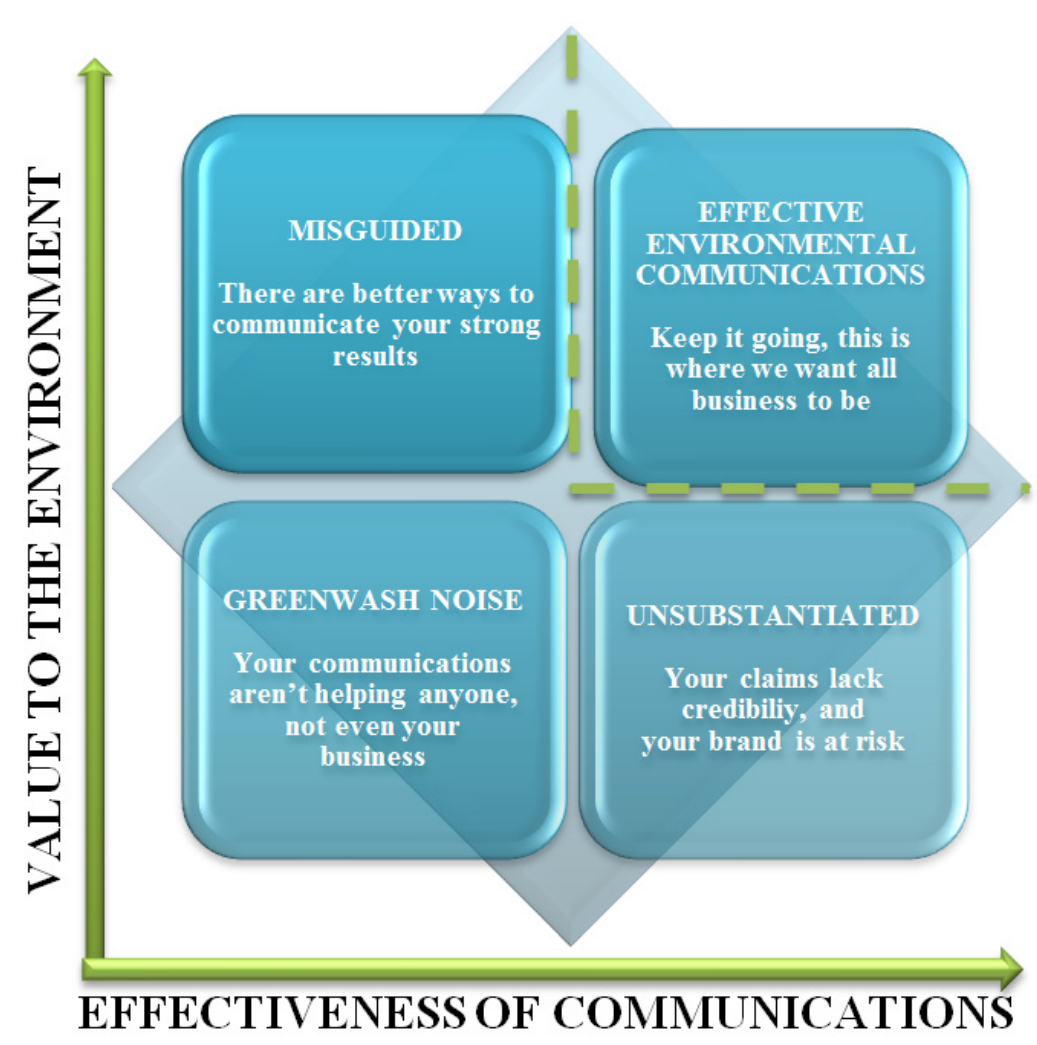

Figure 4. Value to the environment and effectiveness of communications matrix (source: [3]) 


\section{- Misguided Greenwash}

This category includes companies that have made substantial efforts to improve the environmental performance of their products and processes but are unable to communicate these efforts effectively. These companies may be making sweeping generalizations in their claims to try to sound "environmentally friendly" or they may be using language that turns off potential customers. They have the potential to move towards the "Effective Environmental Communications" quadrant by focusing their messages accurately on key impacts backed up with data [3].

\section{- Unsubstantiated Greenwash}

At first glance, these companies seem to be doing commendable work and providing data to back up their claim. However, a deeper dive shows that the company does not deserve as much credit as it seems. It may be lobbying against the very environmental policies it claims to uphold, or it may be putting more resources into its communications than its actual initiatives. False efforts will eventually be uncovered as the public becomes more educated and sensitive to greenwash, and it is only a matter of time that these companies will be sent to the "Greenwash Noise" quadrant [3].

\section{- Greenwash Noise}

In cases where a company says, "we're green", but does not have much to back up this claim, these messages are not compelling to consumers. Much work needs to be done to move these companies to the top right quadrant, but it is feasible. By assessing the company's impacts throughout the value chain, developing and implementing an environmental strategy, and then communicating these efforts accurately, these companies can create a path to the "Effective Environmental Communications" quadrant [3].

\section{- Effective Environmental Communications}

This is the goal we have for all companies. These businesses are improving the environmental and social performance of their products and aligning these efforts throughout various functions within the company. They are able to communicate their efforts so that consumers clearly understand the impacts, and other businesses look to these companies for leadership [3].
What is essential is that greenwashing does not only substitute honest environmental communication, but also, or possibly more importantly, becomes a social issue.

Primary addressees of all corporate environmental communication are called as green consumers. They exclude the following group of products from their sphere of interests [5]:

- Products harmful to health,

- Products generating serious environmental damages during their production, use, and waste management phase,

- Products causing excessive use of resources in their production, use, and waste phase,

- Products generating large amounts of waste, containing resources from endangered species and ecosystems,

- Products produced in a way that is threatening to animals or having negative impact on other countries, among others - developing ones Green consumers comprise of opinion-forming group of socially responsible leaders. Abuses in green marketing practices may negatively impact their decisions and choices. It is worth underlining that through environmental disinformation and over interpretation consumers and wider circle of organization stakeholders are as a matter of fact encouraged to act contrary to the rules of sustainable development. What is even more important is that in a global sense, gaining awareness of greenwashing practices of organizations can have a demotivating effect and discourage conscious consumers, from a given sector or market, to continue further proenvironmental practices, as they prove to be ineffective.

The assumption, that in such circumstances the most socially desirable - and also socially responsible - way is to promote solutions based not on intuitive feelings of consumers but on actual figures presenting seems to be justified. Also the world of science should be involved in creating such, as objective as possible, rules. It seems, an appropriate starting point here can be the LCA method with all its principles. 


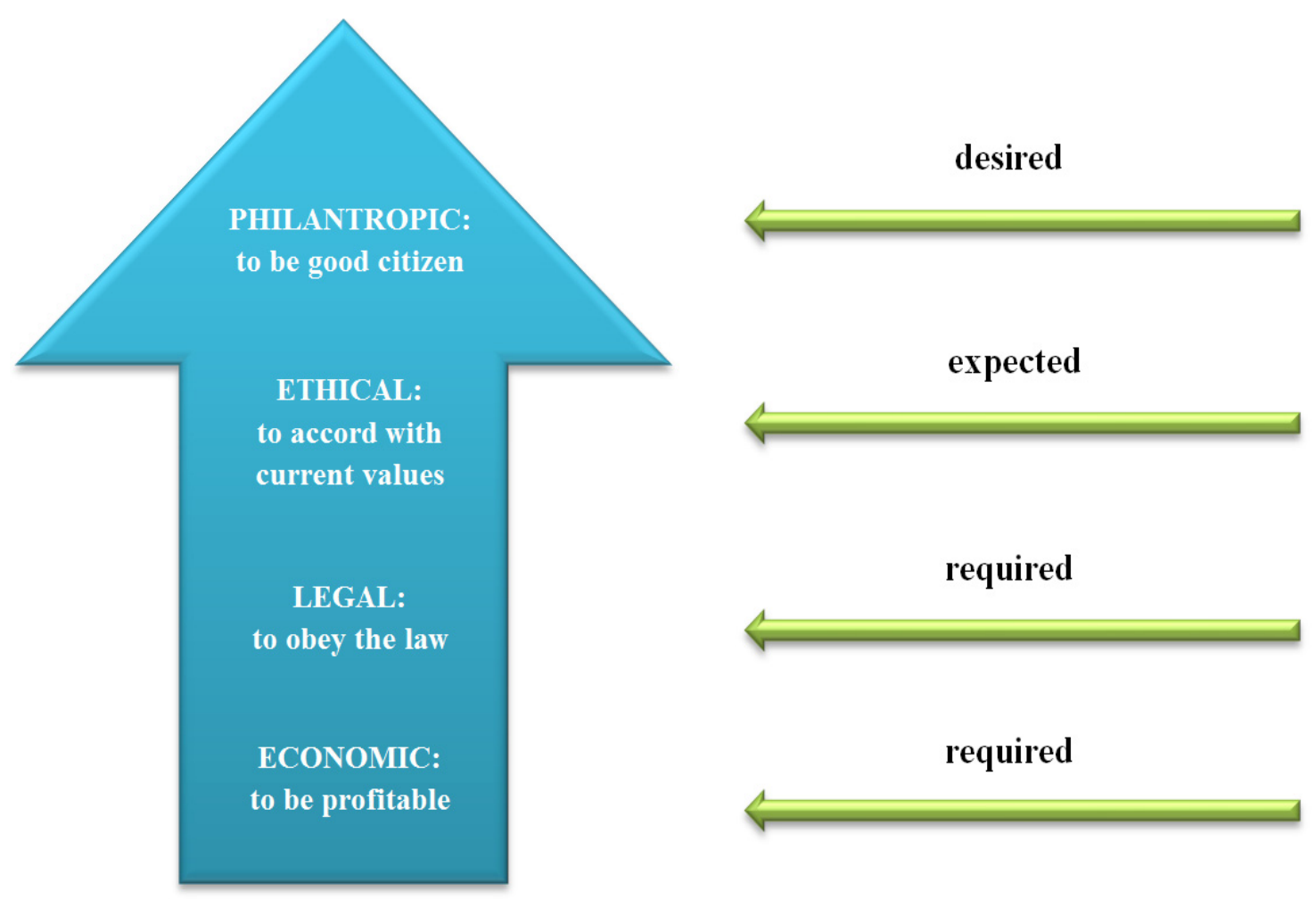

Figure 5. Carroll's model in relation to social expectations (source: [9])

\section{Socially responsible organization}

Referring to the social responsibility and sustainability questions in conjunction with LCA, it is important to describe theoretical basis of CSR. Primary set of guidelines concerning the responsibility of business for the impact on external social environmentstakeholders, and natural environment, is covered by a 2001 Green Paper: Promoting framework for Corporate Social Responsibility [6]. Essential matter that is currently discussed and is also reflected in the mentioned Green Paper, is an understanding of organizational mission. Older publications (Milton Friedman and others [7]) view organization's mission as a way of providing profits for its shareholders. With development of social awareness, the external environment of the organization is currently viewed in broader terms-including not only direct beneficiaries but all stakeholders, representing variety of entities directly and indirectly linked to the organization's operations [10]. Pursuit of acting in harmony with all stakeholders is understood as an element of long term trust building strategy, which will finally come to fruition in form of profits.

Authors of the Green Paper see CSR as a process that gives organizations the ability to manage relationships with groups of stakeholder having a real impact on its activities. Being socially responsible means not only fulfilling legal expectations, but also going beyond compliance and investing "more" into human capital, the environment, and the relations with stakeholders. The experience with investment in environmentally responsible technologies and business practice suggests that going beyond legal compliance can contribute to a company's competitiveness and result in "win-win" effect [6]: good for business and good for the environment.

Valued theoretician of CSR, Archie B. Carroll, created the first and still valid four-stage CSR model. So called Carrols pyramid includes subsequent levels of responsibility: from traditional - economic level, through legislative, ethical, and philanthropic [7]. Profit should therefore be only a baseline responsibility of an organization, followed by adherence to law, acting in accordance with ethical values, and finally by fulfilling civic duties. Interesting approach to Carroll's model was formulated by Magdalena Rojek-Nowosielska [9]. According to her interpretation, legal responsibility is currently required by the external environment and ethical responsibility - even though it is not codified is expressly expected by organization's stakeholders (Fig. 5). 
It can be substantiated that practices based on informational noise and intended ambiguity, such as greenwashing, refer primarily to two of the areas mentioned earlier legislation and ethics. Greenwashing is especially common on the shared area on the border of legislation and non-obligatory actions, considered by the stakeholders as expected. As was mentioned in the introduction, legal level of activity is required, but social expectations and - referring to Carroll's and Rojek-Nowosielska's terms [8], [9] - desires go far beyond it.

For that season law not always can be a good tool to measure CSR: real CSR starts only where the law is obeyed. For this reason it is important to demonstrate to stakeholders all those elements, which are not covered by the law and may be expressed and confirmed by the accurate, comparable data. Also, for development of knowledge about CSR and sustainability, one of the key challenges is to go beyond theoretical considerations and to start to measure. In the future traditional - so called environmental - LCA may be also supplemented by new modules: Life Cycle Costs (LCC) and Social Life Cycle Assessment (S-LCA), which together cover all areas of sustainability conception and give rise to research on a very large scale.

\section{Informational chaos: Oxodegradability}

Due to rapid growth of social awareness, depletion of natural resources and evolution of concept of sustainable development, more significance is placed on the so called environmental efficiency of products. This concept encompasses effectiveness of natural resources usage, minimization of waste creation, and pollution on all stages of a product life cycle, while maintaining sufficient quality of products.

Environmental efficiency is one of the key areas of interests for leading world economists. It was studied by - among others - Stiglitz, Sen and Fitoussi in a report, The Measurement of Economic Performance and Social Progress Revisited [9]. Currently within the field of effective resource use one can observe an emphasis being placed on promoting substitution of traditional plastic with bioplastics, that is, plastic materials produced from renewable resources and biodegradable plastics. Concept of biodegradable plastics is especially becoming a target for greenwashing prac- tices - both in areas of groundless reporting and even outright and deliberate misinformation.

Biodegradability in simple terms denotes biological decay. This phenomenon results from the fact that microorganisms present in the environment, use some materials as a source of nutrition and in turn digest them - what is important is that this process is devoid of any additional chemical additives [11].

Biodegradation does not apply to traditional polymer plastics such as polyethylene or polypropylene. Those materials were designed to be lasting and resistant to the influence of surrounding biological environment. Even so, market is full of substances (additives) that increase the decay of conventional polymers, causing so called oxodegradation.

Producers speaking the language of science and communicating extraordinary environmental benefits of those additives, advance the greenwashing practices exceptionally far.

Oxodegradable additives are not able to convey true biodegradation and what is more, by polluting the composition of plastics they impede waste treatment methods according to sustainable development. This is not the knowledge available for most consumers, but also here helpful can be general product / process /enterprise LCA, taking into account also recycling or waste disposal period and ways.

\section{$5 \quad$ Biodegradability and compostability - testing method}

It is also important to mention LCA and generally product/process/enterprise Life Cycle in the context of biodegradable materials and composting. In the instance of mentioned greenwashing practice of marketing oxodegradable additives as additives granting biodegradability and/or compostability to traditional plastics, objective assessment method that can prove such claims is defined in EN-13432 standard [12].

Truly biodegradable and compostabile can be certified by a number of European certification bodies, such as German DIN Certco (Fig. 6), Belgian Vinçotte (Fig. 7). First two certification bodies are also licensed to grant so called internationally recognized Seedling Logo on compostable products (Fig. 8). 


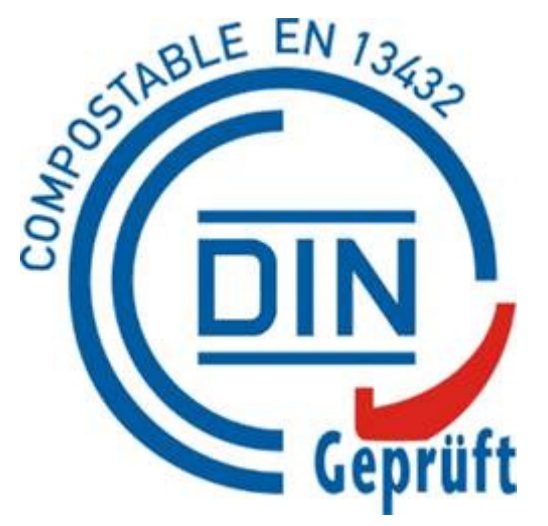

Figure 6. DIN Certco compostability label (source: [10])

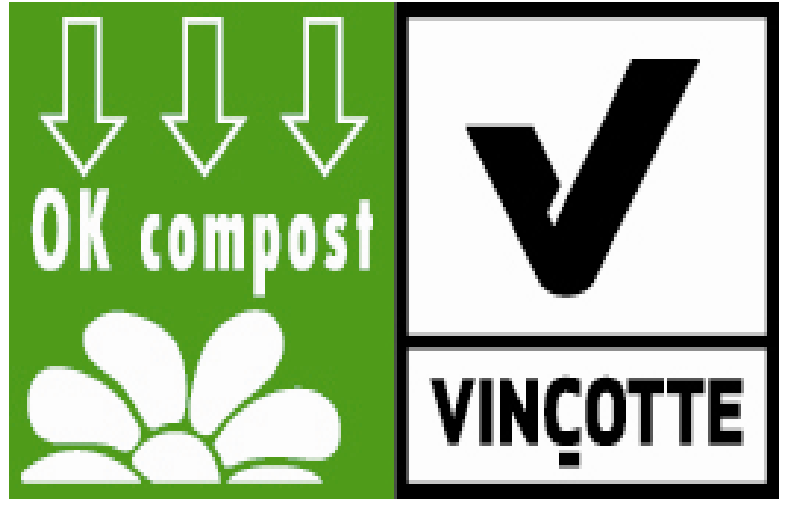

Figure 7. Vinçotte compostability label (source: [10])

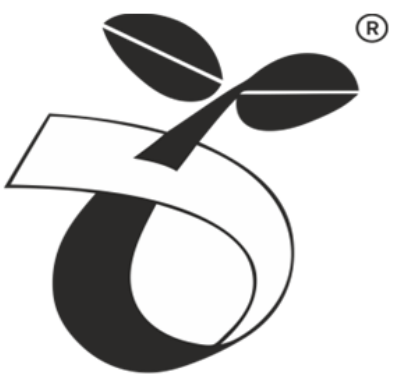

compostable

Figure 8. Seedling Logo compostability label (source: [11])

Those labels, awarded by acknowledged certification bodies on the basis of laboratory testing according to ISO standards are credible confirmations of proenvironmental quality advantage for producers, consumers, authorities at different levels, and all other relevant stakeholders. In the instance of biodegradability and compostability claims, they are one of the best solutions for all organizations deciding to pursue honest green marketing and effectively combat opportunities for greenwashing.

\section{Life cycle assessment - environmental assessment method}

Dissemination of misinformation serving to create environmentally responsible organizational image is one of the more important issues linked to CSR [3]. As mentioned, such practices are contrary to the rule of long term trust building strategy promoted by the Green Paper [6]. However they can be used as more of a short term tactic [13]. What is underlined by the authors on greenwashing, constant observed increase of knowledge and sensitivity of public opinion on similar matters, allows to easily identify scientifically unsupported environmental declarations [3].

Abuses of some of the producers can also translate on more general trend of lost confidence of customers and in effect to limiting expectations of organization's responsibilities to the lowest economic level, which will have a negative impact on the social growth. It is therefore very important to search for more objective methods of environmental impact assessment of organizations on its environment. One of the commonly used method is called LCA, along with so called Carbon Footprint indicator calculation.

In the instance of LCA, life cycle has got a different form than in classical examples. In traditional economic sciences, life cycle of organization or product refers to volume of sales in a given time period. In the instance of LCA from the environmental point of view, it is a study of all material inputs and processes needed to create, distribute, use, and dispose of the product, service, or even entire organization. 


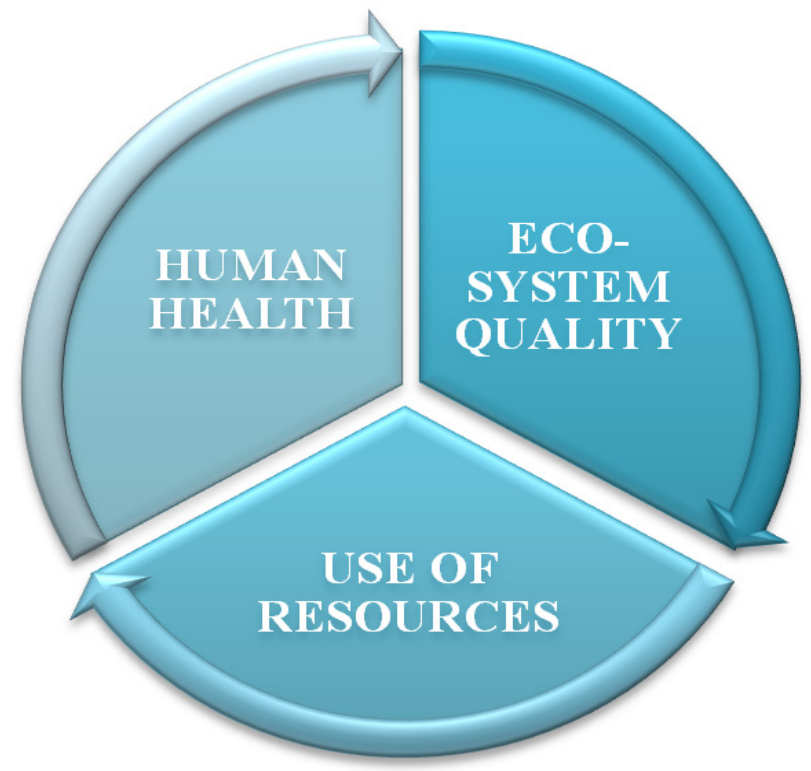

Figure 9. LCA seen as a loop of improvement of environmental damages on human health, ecosystem quality, and use of resources

This study leads to the phase of interpretation that can be used to optimize actions within generated environmental impacts and damages - most commonly in three main categories - human health, eco system quality, and the use of resources (Fig. 9).

LCA is an objective method of assessing such issues as the use of energy, environmental damages, impacts linked to product, processes, or stages of organization's operations within full value chain. LCA gives possibility to calculate detailed and cumulated impact on environment and in the form of environmental declarations provides a proof of conducting effective and sustainable environmental and social communication to the organization itself and to all its direct and indirect stakeholders.

LCA can be perceived on three levels as [14]:

- assessment method of environmental impacts and effects,

- in the instance of specific use, as a tool for this assessment,

- universal philosophy of thinking about an organization in categories of damages and costs that the organization generates; in this sense LCA becomes a full optimization loop, similar in concept to Deming Cycle or Six Sigma.

LCA is an ISO standardized method - LCA concept is described in ISO 14040 [14] standard, and specific aspects in the following standards from the series 14044 [15], 14047 [16], and 14049 [17].

\section{Carbon footprint - analysis}

LCA can also be used to calculate the sum of greenhouse gases emissions generated directly and indirectly within a full life cycle of a given subject matter. This is commonly called a Carbon Footprint (CFP) or a Carbon Profile [19]. CFP calculations are promoted by an organization supporting sustainable and low emission economy called Carbon Trust. The company offers a special carbon reduction label (Fig. 10.) This label can be especially helpful in green marketing as it indicates a total value of greenhouse gases emission (shown as a carbon dioxide equivalent mass) through all processes in life cycle and value chain of assessed product, service, or organization. Similar to the compostability certification, placing a carbon reduction label on the packaging of the product, portrays true and confirmed numerical data of the products' greenhouse gases emissions and helps the consumers in making comparisons and informed decisions, countering dishonest competition.

An example of carbon footprint, comparative analysis of four types of products, utilizing LCA was performed in COBRO - Polish Packaging Research and Development Centre. 

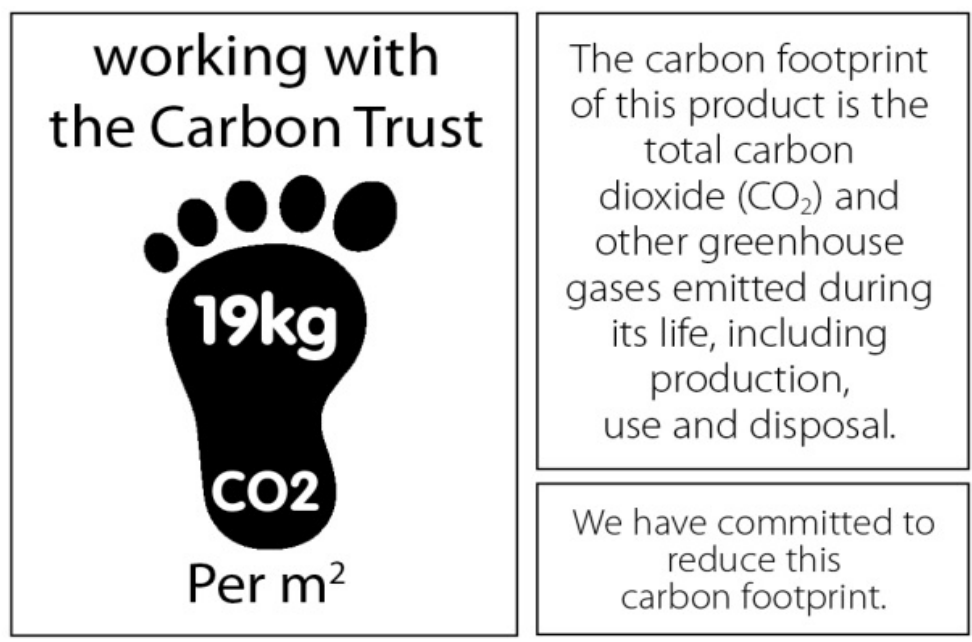

Figure 10. Example of Carbon Reduction Label informing about cooperation with Carbon Trust and displaying greenhouse gases emissions

(source: [11])

Four products were assessed for their greenhouse gases emissions - packaging trays of same volume and shape produced from:

- Polyethylene terephthalate (PET) - traditional fossil based plastic,

- Polypropylene (PP) - traditional fossil based plastic,

- Polyethylene terephthalate (PET) with 30 percent content of recycled polyethylene terephthalate (rPET) - traditional fossil based plastic,

- Polylactic acid (PLA) - bio-based plastic made primarily from corn-starch [19].

The first two types belong to the so called conventional plastic group. Those plastics are not biodegradable nor compostable and are considered to be harmful to the environment in the long term by the general public. This is why currently, the industry seeks for more environmentally sustainable alternatives to those materials, which in certain cases, such as in the example of oxodegradable additives, can lead to the phenomena of greenwashing and speaking the language of science with the objective to influence the consumer. The third type of tested packaging is produced from the same conventional plastic as the first one - PET, however in this example, $70 \%$ of this material is made from the virgin material and $30 \%$ comes from recycling. The producer of this material, took certain real actions that limit the environmental damages during the production process. The last type of material is a fully biodegradable material, which is made entirely from renewable resources, in this case, corn-starch.

Carbon footprint of those products was calculated using LCA software Sima Pro 7.3 by Pré Consultants, using the Intergovernmental Panel on Climate Change (IPCC) Global Warming Potential method. Final numerical results of the study (expressed as kilograms of carbon dioxide equivalent per used functional unit in this instance 1000 packages of each type of packaging) indicating the total sum of all greenhouse gases directly and indirectly emitted by the assessed product can be found in Table 1 .

Obtained results, as expected, show that the highest carbon footprint indicator belongs to packaging from traditional plastic - Polyethylene terephthalate (PET). In the instance of recycled PET - the same plastic, but with 30 percent content of recovered material, the carbon footprint indicator is $0.018 \mathrm{~kg}$ lower, per one package (more than $18 \mathrm{~kg}$ carbon dioxide equivalent for 1000 packages). Carbon footprint of other conventional plastic-PP-is on a similar level to PET. Polylactic acid (PLA) however, which in a functional sense can be considered as a more sustainable substitute of PET, has got a carbon footprint of $60 \%$ of this for the PET.

This type of numerical data obtained by using standardized methodology, along with clear indication of proportions between results for different products and their possible substitutes, should represent a basis for apt environmental assessment and general management of organization's processes. 
Table 1. Carbon footprint indicator results for four tested plastics (source: [19])

\begin{tabular}{|c|c|c|c|c|c|}
\hline \multirow[b]{2}{*}{$\begin{array}{l}\text { Carbon footprint indica- } \\
\text { tor }\end{array}$} & \multirow[b]{2}{*}{ Unit } & \multicolumn{4}{|c|}{ Packaging } \\
\hline & & $\mathrm{PP}$ & PET & $\begin{array}{c}\text { PET } \\
\text { with recycled } \\
\text { PET content } \\
\text { (rPET) }\end{array}$ & PLA \\
\hline Total, including: & \multirow{5}{*}{ 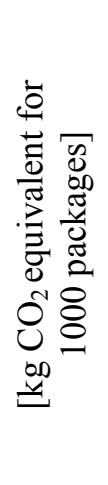 } & 71.54 & 90.72 & 72.56 & 57.83 \\
\hline $\begin{array}{c}\mathrm{CO}_{2} \\
\text { from fossil resources }\end{array}$ & & 63.35 & 81.66 & 65.70 & 88.25 \\
\hline $\begin{array}{c}\mathrm{CH}_{4} \\
\text { from fossil resources }\end{array}$ & & 7.83 & 8.39 & 6.27 & 4.45 \\
\hline $\mathrm{N}_{2} \mathrm{O}$ & & 0.22 & 0.42 & 0.37 & 7.73 \\
\hline $\begin{array}{l}\text { Remaining } \\
\text { (photosynthesis } \mathrm{CO}_{2} \\
\text { included) }\end{array}$ & & 0.13 & 0.25 & 0.21 & $-42.60 *$ \\
\hline
\end{tabular}

* negative value signifies $\mathrm{CO}_{2}$ absorbed from the atmosphere in the photosynthesis process

It allows to avoid a lack of precision and in extreme cases, abuses in determining pro-environmental actions of the organization, on the other hand it can also be used as a method of preventing image crises of organizations in the field of environment and sustainability.

What should be emphasized, concept of Carbon Footprint calculation, can be also used as a general basis for further CSR and sustain development measurement using LCA principles. Such research has been already started by the authors as a part of doctoral thesis prepared in the Faculty of Management of Warsaw University of Technology in cooperation with COBROPackaging Research Institute, under the direction of Professor Stanisław Tkaczyk. LCA method of inputs and outputs analysis and professional LCA software Sima Pro can be useful also for assessment of other parameters relevant to the concept of CSR.

\section{Conclusions}

In the light of presented literature review, LCA principles, and provided examples of results, it seems justified to state, that LCA can be seen as both: promising attempt to introduce specific rules of the CSR or sustainability measurement for the needs of science and the market and as successful way of countering unreliable environmental marketing, known as greenwashing-adopted in different forms: from communication errors, through creating information noise, to finally obvious malpractices - is development of more objective methods of environmental assessment of organization. Those methods should allow to define suitable functional units as a basis of assessment, and show numerical and quantitative values of generated environmental damages. Conducted assessment should also be founded on commonly accepted standards - such as ISO standards. An example of such environmental assessment method is LCA - used for more than 40 years as a method or tool of eco balance, and increasingly viewed as loop of constant organizational improvement. Also future application of this method to recent tasks, especially in area of management sciences and CSR, is promising.

\section{References}

[1] Kotler P., Caslione J.A. - Chaos. Zarzqdzanie imarketing $w$ erze turbulencji (Chaotics: The Business of Managing and Marketing in the Age of Turbulence). MT Biznes, Warsaw 2013, p. 21.

[2] Motivalli J. - A History of Greenwashing: How Dirty Towels Impacted the Green Movement [in] Daily Finance, 12.02.2011.

[3] Horiuchi R., Schuchard R., Shea L., Townsend S. Understanding and Preventing Greenwash: A Business Guide, 2009, pp. 4-7. 
[4] TerraChoice - Six sins of Greenwashing. A study of Environmental Claims in North American Consumer Markets

[http://sinsofgreenwashing.org/index6b90.pdf].

[5] Wiśniewska M., Grudowski P., Pillath E. - Greenwashing sins - the indicators of ecological marketing immaturity [in] Skrzypek E. (ed.) - Maturity Management. Maria Curie Skłodowska University, Lublin 2013, p. 42.

[6] Commission of the European Communities - Green Paper: Promoting framework for Corporate Social Responsibility. COM(2001) 366 final, Brussels, 18.7.2001.

[7] Griffin R. - Podstawy zarzadzania organizacjami (Principles of Management). Wydawnictwo PWN, Warsaw 2004, pp. 120-122.

[8] Carroll A.B. - A three - dimensional conceptual model of corporate social performance [in] Academy of Management Review, No. 4/1979, p. 500.

[9] Rojek-Nowosielska M. - Modelowe ujęcie Społecznej Odpowiedzialności Przedsiębiorstw (Model approach to Corporate Social Responsibility). Prace Naukowe Uniwersytetu Ekonomicznego we Wrocławiu No. 220/2011, p. 33.

[10] Stiglitz J., Sen A., Fitoussi J.P. - The Measurement of Economic Performance and Social Progress Revisited. 2009, p. 22.

[11] Żakowska H., Kržan A., Scandola M., Voevodina I., Horvat P., Ganczewski G. - Bioplastics - Opportunity for the Future. Central Europe project PLASTiCE, WP4 Framework conditions for stimulating market demand, WP4.2 - Draft Transnational Advisory Scheme, 2013, pp. 20-24.

[12] EN 13432:2008 Packaging - Requirements for Packaging Recoverable Through Composting and Biodegradation - Test Scheme and Evaluation Criteria for the Final Acceptance of Packaging.

[13] Gross-Gołacka E. - Społeczna odpowiedzialność organizacji - zrównoważony rozwój (Corporate
Social Responsibility - sustainable development) [at] IV Konferencja Dobre praktyki doskonalenia zarzqdzania - społeczna odpowiedzialność organizacji (IV Conference Good practice of management improvement - Corporate Social Responsibility), Ministerstwo Gospodarki 16 maja 2013.

[14] Tkaczyk S., Ganczewski G., Kuzincow J. - Dojrzałość organizacji a Ocena Cyklu Życia (Organizational Maturity and Life Cycle Assessment) [in] Skrzypek E. (ed.) - Maturity Management. Maria Curie Skłodowska University, Lublin 2013.

[15] ISO 14040:2010 Environmental management Life cycle assessment - Principles and framework.

[16] ISO 14044:2010 Environmental management Life cycle assessment - Requirements and guidelines.

[17] ISO/TR 14047:2012 Environmental management Life cycle assessment - Illustrative examples on how to apply ISO 14044 to impact assessment situations.

[18] ISO/TR 14049:2012 Environmental management Life cycle assessment - Illustrative examples on how to apply ISO 14044 to goal and scope definition and inventory analysis.

[19] Żakowska H., Ganczewski G. - Ocena cyklu życia oraz ślad węlowy dla opakowań [in] Problemy jakości, Issue 7-8/2012, pp. 57-60.

[20] Żakowska H., Ganczewski G., Nowakowski K. Ocena cyklu życia (LCA) opakowań termoformowanych wykonanych z PLA, PET, RPET i PP (Life Cycle Assessment (LCA) of thermoformed packaging made from PLA, PET, RPET and PP) [in] Materiaty opakowaniowe $z$ kompostowalnych tworzyw polimerowych (Packaging materials from compostable polymer materials), Kowalczuk M., Żakowska H. (ed.), COBRO, Warsaw 2012, pp. 193-205. 